\title{
Transferrin polymorphism and genetic differentiation in Cervus elaphus L. (European red deer) populations
}

\author{
SVEN HERZOG, ${ }^{*}$ CHRISTINE MUSHÖVEL, † HANS H. HATTEMER, ${ }^{*}$ \\ ALEXANDER HERZOG $\dagger$ \\ *Universität Göttingen, Abteilung Forstgenetik und Forstpflanzenzüchtung, Büsgenweg 2, D-3400 Göttingen, \\ Bundesrepublik Deutschland and †Universität Giessen, Fachgebiet Veterinärmedizinische Genetik und Zytogenetik, \\ Hofmann-strasse 10, D-6300 Giessen, Bundesrepublik Deutschland
}

\begin{abstract}
A study of transferrin in 11 different European populations of Cervus elaphus as well as in one Cervus elephus $\times$ Cervus nippon hybrid population has revealed a polymorphism of this protein. Genetic analysis suggests that it is controlled by one gene locus with three codominant alleles. The allele frequencies allow a clear discrimination not only between the hybrid population and pure red deer but also between different Continental red deer populations. Comparison of the genotypic structures with the Hardy-Weinberg structure shows no significant deviation. Genetic variation within and differentiation between populations is evaluated for the transferrin gene locus using different measures. Average heterozygosities have been calculated for five populations including the results of previous studies on 14 other protein systems. Some management implications of the present results are discussed.
\end{abstract}

Keywords: Cervus elaphus, differentiation, genetic control, protein polymorphism.

\section{Introduction}

Red deer (Cervus elaphus L.) is one of the last large wild mammals living in Central Europe. The populations are subjected to intensive management and, in addition, they are increasingly becoming isolated by traffic routes, settlements, industrial plants as well as by hunting legislation. Thus there is a strong need to assess the genetic implications of the recent anthropogenic influences on the red deer populations. One purpose of the present study is to evaluate the genetic structures of a number of European populations for the transferrin $(T f)$ gene locus. In addition, the present results for the $T f$ gene locus are combined with those for 14 previously studied protein systems (Herzog, 1988a, b, 1990), thus allowing the genetic variation and differentiation to be evaluated on a gene pool basis, represented by a total of 15 protein systems.

Transferrin has been shown to be one of the most variable protein systems in mammals and birds. Among the genus Cervus, the transferrin variability shows a wide range between the species. Whereas in European red deer it is quite variable (McDougall \& Lowe, 1968; Kravchenko \& Kravchenko, 1971;
Bergmann, 1976; Gyllensten et al., 1980, 1983), the only studied American wapiti population (Cameron \& Vyse, 1978) as well as most fallow deer populations are monomorphic and fixed for one putative allele (McDougall \& Lowe, 1968; Pemberton \& Smith, 1985; Hartl et al., 1986), whereas others have maintained transferrin variations (Herzog, 1989). In sika deer (Cervus nippon Temminck), only one park population has been studied by McDougall \& Lowe (1968) and was also found to be monomorphic.

Genetic analysis of incomplete (Bergmann, 1976; red deer) and complete families (Herzog, 1989; fallow deer) provided evidence for the hypothesis of genetic control by one gene locus. The present study includes the genetic analysis of complete red deer $\times$ sika deer hybrid families.

\section{Materials and methods}

A total of 467 animals from seven natural red deer populations (Lüneburger Heide, Harz, Solling, Reinhardswald, Spessart, Soonwald, Achenkirch) in Central Europe as well as from five enclosed populations (Wicklow, Olderdissen, Reinhardswaldgatter, 


\title{
Transferrin polymorphism and genetic differentiation in Cervus elaphus L. (European red deer) populations
}

\author{
SVEN HERZOG, ${ }^{*}$ CHRISTINE MUSHÖVEL, † HANS H. HATTEMER, ${ }^{*}$ \\ ALEXANDER HERZOG $\dagger$ \\ *Universität Göttingen, Abteilung Forstgenetik und Forstpflanzenzüchtung, Büsgenweg 2, D-3400 Göttingen, \\ Bundesrepublik Deutschland and †Universität Giessen, Fachgebiet Veterinärmedizinische Genetik und Zytogenetik, \\ Hofmann-strasse 10, D-6300 Giessen, Bundesrepublik Deutschland
}

\begin{abstract}
A study of transferrin in 11 different European populations of Cervus elaphus as well as in one Cervus elephus $\times$ Cervus nippon hybrid population has revealed a polymorphism of this protein. Genetic analysis suggests that it is controlled by one gene locus with three codominant alleles. The allele frequencies allow a clear discrimination not only between the hybrid population and pure red deer but also between different Continental red deer populations. Comparison of the genotypic structures with the Hardy-Weinberg structure shows no significant deviation. Genetic variation within and differentiation between populations is evaluated for the transferrin gene locus using different measures. Average heterozygosities have been calculated for five populations including the results of previous studies on 14 other protein systems. Some management implications of the present results are discussed.
\end{abstract}

Keywords: Cervus elaphus, differentiation, genetic control, protein polymorphism.

\section{Introduction}

Red deer (Cervus elaphus L.) is one of the last large wild mammals living in Central Europe. The populations are subjected to intensive management and, in addition, they are increasingly becoming isolated by traffic routes, settlements, industrial plants as well as by hunting legislation. Thus there is a strong need to assess the genetic implications of the recent anthropogenic influences on the red deer populations. One purpose of the present study is to evaluate the genetic structures of a number of European populations for the transferrin $(T f)$ gene locus. In addition, the present results for the $T f$ gene locus are combined with those for 14 previously studied protein systems (Herzog, 1988a, b, 1990), thus allowing the genetic variation and differentiation to be evaluated on a gene pool basis, represented by a total of 15 protein systems.

Transferrin has been shown to be one of the most variable protein systems in mammals and birds. Among the genus Cervus, the transferrin variability shows a wide range between the species. Whereas in European red deer it is quite variable (McDougall \& Lowe, 1968; Kravchenko \& Kravchenko, 1971;
Bergmann, 1976; Gyllensten et al., 1980, 1983), the only studied American wapiti population (Cameron \& Vyse, 1978) as well as most fallow deer populations are monomorphic and fixed for one putative allele (McDougall \& Lowe, 1968; Pemberton \& Smith, 1985; Hartl et al., 1986), whereas others have maintained transferrin variations (Herzog, 1989). In sika deer (Cervus nippon Temminck), only one park population has been studied by McDougall \& Lowe (1968) and was also found to be monomorphic.

Genetic analysis of incomplete (Bergmann, 1976; red deer) and complete families (Herzog, 1989; fallow deer) provided evidence for the hypothesis of genetic control by one gene locus. The present study includes the genetic analysis of complete red deer $\times$ sika deer hybrid families.

\section{Materials and methods}

A total of 467 animals from seven natural red deer populations (Lüneburger Heide, Harz, Solling, Reinhardswald, Spessart, Soonwald, Achenkirch) in Central Europe as well as from five enclosed populations (Wicklow, Olderdissen, Reinhardswaldgatter, 
Opel, Lehmkaule) of different origin have been studied (see Table 1). Of the latter, Wicklow is an Irish hybrid population of red deer and sika deer (Cervus nippon) such as are very common in the Co. Wicklow region as wild living populations. Olderdissen is a park popula- tion of unknown and presumably mixed origin. Reinhardswaldgatter is an enclosed population that was established in the 18th century by sampling animals only from the natural Reinhardswald population. The smallest known population size was about

Table 1 Origin of the animals, sample size, genotypic and allelic structures for the Tf gene locus, corresponding Hardy-Weinberg structures (HWS) and $G$-tests for Hardy-Weinberg equilibrium

\begin{tabular}{|c|c|c|c|c|c|c|}
\hline $\begin{array}{l}\text { Origin and } \\
\text { sample size }\end{array}$ & $\begin{array}{l}\text { Genotype } \\
\text { resp. allele }\end{array}$ & $\begin{array}{l}\text { Number } \\
\text { observed }\end{array}$ & HWS & $\begin{array}{l}\text { Frequency } \\
\text { observed }\end{array}$ & HWS & $\begin{array}{l}\hat{G} \\
\text { (d.f. }=1)\end{array}$ \\
\hline Lüneburger & $T f^{\text {aa }}$ & 8 & 7.584 & 0.333 & 0.316 & \\
\hline Heide & $T f^{\mathrm{ab}}$ & 11 & 11.784 & 0.458 & 0.491 & \\
\hline (LÜN) & $T f^{\mathrm{bb}}$ & 5 & 4.584 & 0.208 & 0.191 & 0.143 n.s. \\
\hline \multirow[t]{2}{*}{24} & $T f^{\mathrm{a}}$ & 27 & - & 0.562 & - & - \\
\hline & $T f^{\mathrm{b}}$ & 21 & - & 0.437 & - & - \\
\hline Harz & $T f^{\mathrm{aa}}$ & 5 & 5.063 & 0.313 & 0.316 & \\
\hline (HAR) & $T f^{\mathrm{ab}}$ & 8 & 7.872 & 0.500 & 0.492 & \\
\hline \multirow[t]{3}{*}{16} & $T f^{\mathrm{bb}}$ & 3 & 3.063 & 0.188 & 0.191 & 0.004 n.s. \\
\hline & $T f^{\mathrm{a}}$ & 18 & - & 0.563 & - & \\
\hline & $T f^{\mathrm{b}}$ & 14 & - & 0.438 & - & - \\
\hline Solling & $T f^{\mathrm{aa}}$ & 36 & 34.540 & 0.818 & 0.785 & \\
\hline$(\mathrm{SOL})$ & $T f^{\mathrm{ab}}$ & 6 & 8.888 & 0.136 & 0.202 & \\
\hline \multirow[t]{3}{*}{44} & $T f^{\mathrm{bb}}$ & 2 & 0.572 & 0.046 & 0.013 & 1.800 n.s. \\
\hline & $T f^{a}$ & 78 & - & 0.886 & - & \\
\hline & $T f^{\mathrm{b}}$ & 10 & - & 0.114 & - & - \\
\hline \multirow{2}{*}{$\begin{array}{l}\text { Reinhardswald } \\
\text { (REI) }\end{array}$} & $T f^{\text {aa }}$ & 81 & 78.960 & 0.771 & 0.752 & \\
\hline & $T f^{\mathrm{ab}}$ & 20 & 24.255 & 0.191 & 0.231 & \\
\hline \multirow[t]{3}{*}{105} & $T f^{\mathrm{bb}}$ & 4 & 1.890 & 0.038 & 0.018 & 2.414 n.s. \\
\hline & $T f^{\mathrm{a}}$ & 182 & - & 0.876 & - & \\
\hline & $T f^{b}$ & 28 & - & 0.133 & - & - \\
\hline Spessart & $T f^{\text {aa }}$ & 17 & 17.199 & 0.810 & 0.819 & \\
\hline (SPE) & $T f^{\mathrm{ab}}$ & 4 & 3.612 & 0.190 & 0.172 & \\
\hline \multirow[t]{3}{*}{21} & $T f^{\mathrm{bb}}$ & 0 & 0.189 & 0.000 & 0.009 & n.t. \\
\hline & $T f^{\mathrm{a}}$ & 38 & - & 0.905 & - & \\
\hline & $T f^{\mathrm{b}}$ & 4 & - & 0.095 & - & - \\
\hline Soonwald & $T f^{\mathrm{aa}}$ & 28 & 27.370 & 0.824 & 0.805 & \\
\hline (SOO) & $T f^{\mathrm{ab}}$ & 5 & 6.290 & 0.147 & 0.185 & \\
\hline \multirow[t]{3}{*}{34} & $T f^{\mathrm{bb}}$ & 1 & 0.347 & 0.029 & 0.011 & 0.946 n.s. \\
\hline & $T f^{a}$ & 61 & - & 0.897 & - & \\
\hline & $T f^{\mathrm{b}}$ & 6 & - & 0.103 & - & - \\
\hline Achenkirch & $T f^{\text {aa }}$ & 42 & 38.700 & 0.840 & 0.774 & \\
\hline$(\mathrm{ACH})$ & $T f^{\mathrm{ab}}$ & 4 & 7.900 & 0.080 & 0.158 & \\
\hline \multirow[t]{7}{*}{50} & $T f^{\mathrm{bb}}$ & 2 & 0.400 & 0.040 & 0.008 & \\
\hline & $T f^{\mathrm{ac}}$ & 0 & 2.650 & 0.000 & 0.053 & \\
\hline & $T f^{\mathrm{bc}}$ & 1 & 0.250 & 0.020 & 0.005 & \\
\hline & $T f^{\mathrm{cc}}$ & 1 & 0.050 & 0.020 & 0.001 & n.t. \\
\hline & $T f^{a}$ & 88 & - & 0.880 & - & \\
\hline & $T f^{\mathrm{b}}$ & 9 & - & 0.090 & - & \\
\hline & $T f^{\mathfrak{c}}$ & 3 & - & 0.030 & - & - \\
\hline Wicklow & $T f^{\text {aa }}$ & 4 & 3.248 & 0.072 & 0.058 & \\
\hline (WI) & $T f^{\mathrm{ab}}$ & 19 & 20.496 & 0.339 & 0.366 & \\
\hline \multirow[t]{3}{*}{56} & $T f^{\mathrm{bb}}$ & 33 & 32.256 & 0.589 & 0.576 & 0.311 n.s. \\
\hline & $T f^{a}$ & 27 & - & 0.241 & - & \\
\hline & $T f^{\mathrm{b}}$ & 85 & - & 0.759 & - & - \\
\hline
\end{tabular}


Table 1 Continued

\begin{tabular}{|c|c|c|c|c|c|c|}
\hline $\begin{array}{l}\text { Origin and } \\
\text { sample size }\end{array}$ & $\begin{array}{l}\text { Genotype } \\
\text { resp. allele }\end{array}$ & $\begin{array}{l}\text { Number } \\
\text { observed }\end{array}$ & HWS & $\begin{array}{l}\text { Frequency } \\
\text { observed }\end{array}$ & HWS & $\begin{array}{l}\hat{G} \\
(\text { d.f. }=1)\end{array}$ \\
\hline Reinhardswaldgatter & $T f^{\text {aa }}$ & 11 & 11.700 & 0.611 & 0.650 & \\
\hline (RE) & $T f^{\mathrm{ab}}$ & 7 & 5.634 & 0.389 & 0.313 & \\
\hline \multirow[t]{3}{*}{18} & $T f^{\mathrm{bb}}$ & 0 & 0.684 & 0.000 & 0.038 & n.t. \\
\hline & $T f^{\mathrm{a}}$ & 29 & - & 0.806 & & \\
\hline & $T f^{\mathrm{b}}$ & 7 & - & 0.194 & - & - \\
\hline Olderdissen & $T f^{\mathrm{aa}}$ & 5 & 3.375 & 0.556 & 0.375 & \\
\hline$(\mathrm{OL})$ & $T f^{\mathrm{ab}}$ & 1 & 1.836 & 0.111 & 0.204 & \\
\hline \multirow[t]{7}{*}{9} & $T f^{\mathrm{bb}}$ & 1 & 0.252 & 0.111 & 0.028 & \\
\hline & $T f^{a c}$ & 0 & 2.448 & 0.000 & 0.272 & \\
\hline & $T f^{\mathrm{bc}}$ & 0 & 0.660 & 0.000 & 0.074 & \\
\hline & $T f^{\mathfrak{c c}}$ & 2 & 0.441 & 0.222 & 0.049 & n.t. \\
\hline & $T f^{\mathrm{a}}$ & 11 & - & 0.612 & - & \\
\hline & $T f^{\mathrm{b}}$ & 3 & - & 0.167 & - & \\
\hline & $T f^{c}$ & 4 & - & 0.222 & - & - \\
\hline Opel & $T f^{\text {aa }}$ & 45 & 45.784 & 0.763 & 0.776 & \\
\hline (OP) & $T f^{\mathrm{ab}}$ & 14 & 12.331 & 0.237 & 0.209 & \\
\hline \multirow[t]{3}{*}{59} & $T f^{\mathrm{bb}}$ & 0 & 0.826 & 0.000 & 0.014 & n.t. \\
\hline & $T f^{a}$ & 104 & - & 0.881 & - & \\
\hline & $T f^{\mathrm{b}}$ & 14 & - & 0.119 & - & - \\
\hline \multirow{5}{*}{$\begin{array}{l}\text { Lehmkaule } \\
\text { (LE) } \\
31\end{array}$} & $T f^{\mathrm{aa}}$ & 8 & 9.300 & 0.258 & 0.300 & \\
\hline & $T f^{\mathrm{ab}}$ & 18 & 15.345 & 0.581 & 0.495 & \\
\hline & $T f^{\mathrm{bb}}$ & 5 & 6.324 & 0.161 & 0.204 & 0.987 n.s. \\
\hline & $T f^{\mathrm{a}}$ & 34 & - & 0.548 & - & \\
\hline & $T f^{\mathrm{b}}$ & 28 & - & 0.452 & - & - \\
\hline
\end{tabular}

n.s. $=$ Not significant, n.t. $=$ not tested; WI,RE,OL,OP,LE are enclosed populations, for details see text.

Table 2 Segregation results of transterrin in complete families. All offspring of mating types with the same phenotype have been pooled

\begin{tabular}{|c|c|c|c|c|c|c|}
\hline \multirow[b]{2}{*}{ Mating type } & \multirow{2}{*}{$\begin{array}{l}\text { Number } \\
\text { of pairs }\end{array}$} & \multicolumn{4}{|c|}{ Offspring (expected numbers in brackets) } & \multirow{2}{*}{$\begin{array}{l}\text { Exact level of } \\
\text { significance }\end{array}$} \\
\hline & & Total & $T f^{\text {a }}$ & $T f^{\mathrm{ab}}$ & $T f^{\mathrm{bb}}$ & \\
\hline$T f^{\mathrm{aa}} \times T f^{\mathrm{ab}}$ & 1 & 1 & $0(0.5)$ & $1(0.5)$ & $0(0)$ & 1.0 \\
\hline$T f^{\mathrm{ab}} \times T f^{\mathrm{ab}}$ & 6 & 11 & $2(2.75)$ & $6(5.5)$ & $3(2.75)$ & 1.0 \\
\hline$T f^{\mathrm{ab}} \times T f^{\mathrm{bb}}$ & 2 & 2 & $0(0)$ & $0(1)$ & $2(1)$ & 0.5 \\
\hline$T f^{\mathrm{bb}} \times T f^{\mathrm{bb}}$ & 2 & 2 & $0(0)$ & $0(0)$ & $2(2)$ & 1.0 \\
\hline
\end{tabular}

200 animals. The Opel enclosure was established with one male and three females from Hungary and one female of unknown origin, and the Lehmkaule enclosure was established with one male and one female from Hungary and three females from Yugoslavia.

Blood samples of $10 \mathrm{ml}$ were taken from the Vena jugularis immediately post mortem or after immobilization into heparinized tubes and kept under refrigeration during transport. The processing of the samples, separation by horizontal isoelectric focusing in poly- acrylamide gels and by electrophoresis in starch gels, as well as the staining procedure followed Mushövel (1986) and Herzog (1988a). Transferrin bands have been identified by ${ }^{59} \mathrm{Fe}$ autoradiography. The mode of inheritance was tested by analysis of the mating types shown in Table 2 . Due to the relatively small number of offspring, a general problem in the genetic analysis of large mammals, all offspring of mating types with the same phenotype were pooled and the exact level of significance was calculated by the exact test (see Tate \& Clelland, 1957). Comparison of the observed genetic 
structures with the corresponding Hardy-Weinberg structure was based on the $G$-test due to the relatively low frequencies of the rarer allele (see Weber, 1978).

Interpretation of the results is mainly based on the concepts of genetic variation within and differentiation between demes as described in detail by Gregorius \& Roberds (1986) and Gregorius (1987, 1988).

\section{Results}

In the investigated animals, phenotypic varition of transferrin was found. Five phenotypes have been observed, three of which are common. The other two are rare and have been observed in only two populations. The association of the protein bands leads us to the hypothesis of genetic control by one gene locus with three (two common, $T f^{\mathrm{a}}$ and $T f^{\mathrm{b}}$, and one rare, $T f^{c}$ ) alleles. Figure 1 shows the corresponding homozygote phenotypes. The analysis of the mating types shown in Table 2 provides evidence for this hypothesis.

Comparison of the present phenotypes with standard serum samples, from the study of Bergmann (1976) on the same gel, shows that the alleles $T f^{\mathrm{a}}, T f^{\mathrm{b}}$ and $T f^{\mathrm{c}}$ of the present study are identical to the $T f^{\mathrm{A}}$, $T f^{\mathrm{B}}$ and $T f^{\mathrm{C}}$ in Bergmann's notation and therefore may also correspond to the alleles designated as $T f^{100}, T f^{83}$ and $T f^{65}$ by Gyllensten et al. (1980). The alleles designated $T f^{\text {ab }}$ and $T f^{\text {bc }}$ by McDougall \& Lowe (1968) may also be identical to $T f^{\mathrm{a}}$ and $T f^{\mathrm{b}}$ of the present study, whereas $T f^{c}$ seems not to be responsible for the occurrence of the 'uncommon phenotypes' shown by McDougal \& Lowe (1968).

The study of allelic and genotypic frequencies in the different populations (Table 1) shows that all red deer populations as well as the red deer $\times$ sika deer hybrid population are polymorphic of the $T f$ gene locus. In the latter, the allele $T f^{\mathrm{b}}$ is the most frequent one, whereas in pure red deer populations quite the contrary is the case. The rare allele $T f^{c}$ has been observed only in the Austrian Achenkirch population and in one park population of unknown origin. Comparison of the observed genetic structures of the populations with the corresponding Hardy-Weinberg expectations reveals no significant deviation in most cases. However, in the samples from some populations no homozygotes for the rarer allele have been found.

The (actual) heterozygosity was calculated on the basis of 15 protein systems including 12 monomorphic systems studied by Herzog (1988a, b; see Table 3 ). The highest value was found for the Wicklow hybrid population $\left(H_{\mathrm{A}}=0.051\right)$. The average heterozygosity for the four German populations Luneburger Heide, Harz, Solling and Reinhardswald is 0.033 , ranging from 0.023 (Solling) to 0.046 (Harz).

Based on the allele frequencies, pairwise genetic (genic) distances $d_{0}$ (Gregorius, 1974) as well as Nei's (1972) $D$, values were calculated for all 12 populations. Table 4 shows the results for the transferrin system. In addition, for four German sites (Lüneburger Heide, Harze, Solling, Reinhardswald) as well as for the Irish hybrid population, the multilocus gene pool distances have been calculated on the basis of a total of 15 protein systems that have previously studied in these populations (Herzog, 1988a, b). The results are shown in Table 5.

Table 6 shows the genetic differentiation $D_{j}$ as well as $\delta$ (Gregorius \& Roberds, 1986) between populations on the basis of gene frequencies. Therefore, this measure is directly comparable to the measure $F_{\mathrm{ST}}$ (Wright, 1978). First, it was evaluated for all populations studied. In addition, separate calculations were made for all Continental (i.e. pure) red deer populations and for all natural populations.

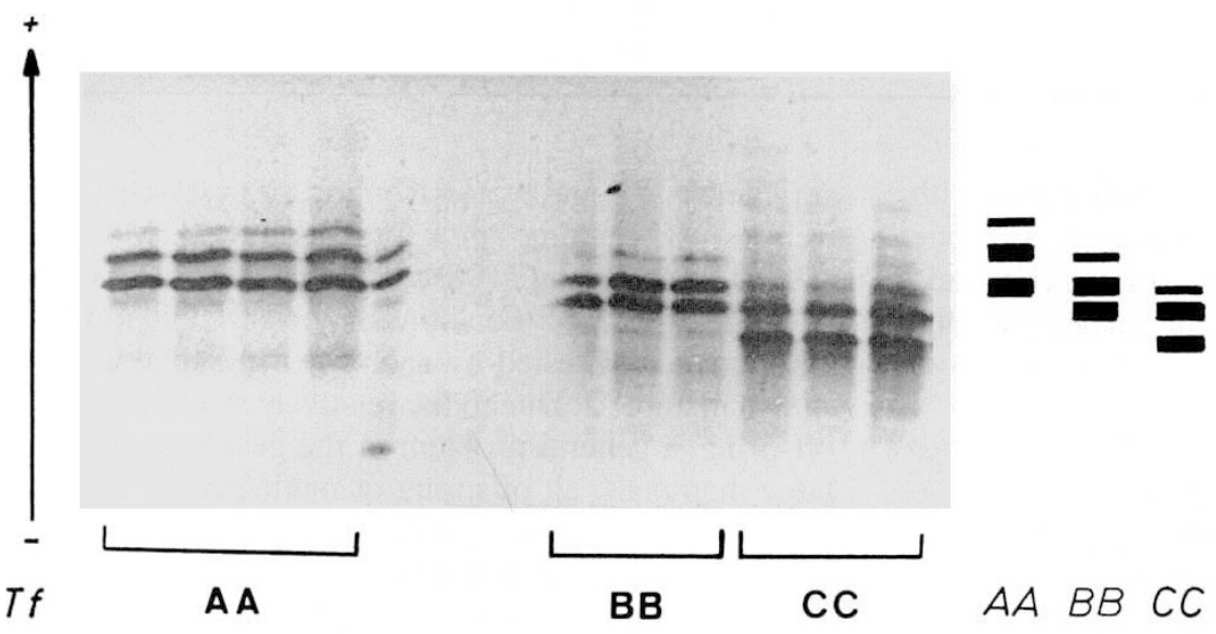

Fig. 1 Photographic and schematic representation of transferrin phenotypes observed in this study. 


\section{Discussion}

\section{Genotype and allele frequencies}

For the transferrin gene locus, the genotypic stuctures show no evidence of departure from Hardy-Weinberg proportions within the red deer populations. The cases where homozygotes for the rarer allele are lacking may be due to a sampling error, the expected number of these genotypes being less than 1 in all cases in question. A lack of heterozygotes as described by Gyllensten et al. (1980) was not observed. The differences in the genotype and allele frequencies between the populations are striking. In the Wicklow population, the $T f^{\mathrm{b}}$ allele is the most common. This observation is in accordance with the results of McDougall \& Lowe (1968), who in a small sample of 10 animals from a British sika deer park population only found one allele that may be identical to $T f^{\mathrm{b}}$, which has also been found to be the most common allele in fallow deer (Herzog, 1989). It is assumed that the frequencies mainly result from hybridization between red and sika deer.

In the pure red deer populations, $T f^{\mathrm{a}}$ is the most common and $T f^{\mathrm{b}}$ is the rarer allele whereas $T f^{\mathrm{c}}$ has

Table 3 Average actual heterozygosities $\left(\bar{H}_{\mathrm{A}}\right)$ over 15 gene loci (for details see text)

\begin{tabular}{ll}
\hline Origin & Actual heterozygosity $\tilde{H}_{\mathrm{A}}$ \\
\hline Lüneburger Heide & 0.036 \\
Harz & 0.046 \\
Solling & 0.023 \\
Reinhardswald & 0.027 \\
Wicklow & 0.051 \\
\hline
\end{tabular}

only been found sporadically. The reasons for this phenomenon can only be speculated upon. On first sight, the results of Pemberton et al. (1988) may give an explanation. The authors found differences in the intensity of selection against two homozygotes, and there is good evidence that the more intensively selected transferrin homozygote found by Pemberton et al. (1988) corresponds to the rarer $T f^{\mathrm{bb}}$ in the present study. However, if we assume selection as the major reason for the observed allele and genotype frequencies, we should not expect viability selection due to the Hardy-Weinberg proportions in all populations tested. Moreover, we should have to assume that selection acts very specifically depending on the environment and/or on the species and population. Only the latter may explain the observations that in fallow deer (Herzog, $1989)$ as well as in the red deer $\times$ sika deer hybrid population the allele $T f^{\mathrm{b}}$ and the genotype $T f^{\mathrm{bb}}$ are most common and that the frequencies of $T f^{\mathrm{a}}$ and $T f^{\mathrm{b}}$ are nearly 50 per cent each in the large natural Lüneburger Heide and Harz populations. Thus a selection hypothesis entails a number of uncertain assumptions. It seems to be more plausible that random events such as bottleneck or founder effects during the history of the populations would have been responsible for the recent genetic structures, perhaps slightly re-inforced by a selective disadvantage of one homozygote. The absence of the very rare $T f^{\mathrm{c}}$ in most populations may be due to sampling error and/or random effects.

The first investigation based on transferrin allele frequencies was that of Bergmann (1976). He studied eight West German provenances and found a transferrin polymorphism involving the same alleles as in the present study. The results show neighbouring populations to be more similar than provenances separated by larger distances, as well as clinal variation of the allele frequencies in the north-south direction.

Table 4 Pairwise genetic (genic) distances $d_{0}$ (top) and $D$ (bottom) for the $T f$ gene locus between the different populations

\begin{tabular}{lllllllllllll}
\hline & LÜN & HAR & SOL & REI & SPE & SOO & ACH & WI & OL & RE & OP & LE \\
\hline LUN & - & 0.001 & 0.324 & 0.305 & 0.343 & 0.335 & 0.348 & 0.322 & 0.271 & 0.244 & 0.319 & 0.014 \\
HAR & 0.149 & - & 0.324 & 0.305 & 0.343 & 0.335 & 0.348 & 0.322 & 0.271 & 0.244 & 0.319 & 0.015 \\
SOL & 0.149 & 0.149 & - & 0.019 & 0.019 & 0.011 & 0.030 & 0.645 & 0.275 & 0.080 & 0.005 & 0.338 \\
REI & 0.126 & 0.136 & 0.000 & - & 0.038 & 0.030 & 0.043 & 0.625 & 0.256 & 0.061 & 0.014 & 0.319 \\
SPE & 0.163 & 0.164 & 0.000 & 0.001 & - & 0.008 & 0.030 & 0.664 & 0.294 & 0.099 & 0.024 & 0.357 \\
SOO & 0.157 & 0.158 & 0.000 & 0.001 & 0.000 & - & 0.030 & 0.656 & 0.271 & 0.091 & 0.016 & 0.349 \\
ACH & 0.166 & 0.166 & 0.001 & 0.002 & 0.001 & 0.001 & - & 0.669 & 0.269 & 0.104 & 0.030 & 0.362 \\
WI & 0.194 & 0.193 & 0.836 & 0.813 & 0.915 & 0.893 & 0.922 & - & 0.593 & 0.565 & 0.640 & 0.307 \\
OL & 0.138 & 0.138 & 0.067 & 0.064 & 0.071 & 0.069 & 0.060 & 0.669 & - & 0.222 & 0.270 & 0.286 \\
RE & 0.093 & 0.093 & 0.006 & 0.004 & 0.009 & 0.007 & 0.010 & 0.659 & 0.058 & - & 0.075 & 0.258 \\
OP & 0.150 & 0.146 & 0.000 & 0.000 & 0.000 & 0.000 & 0.001 & 0.850 & 0.067 & 0.005 & - & 0.333 \\
LE & 0.000 & 0.000 & 0.206 & 0.143 & 0.182 & 0.176 & 0.120 & 0.174 & 0.150 & 0.107 & 0.163 & - \\
\hline
\end{tabular}


Table 5 Pairwise multilocus gene pool distances $d_{0}$ (top) and $D$ (bottom) for a minimum of 15 gene loci between the different populations

\begin{tabular}{llllll}
\hline & $\begin{array}{l}\text { Lüneburger } \\
\text { Heide }\end{array}$ & Harz & Solling & Reinhardswald & Wicklow \\
\hline Lüneb. Heide & - & 0.005 & 0.030 & 0.026 & 0.115 \\
Harz & 0.004 & - & 0.024 & 0.021 & 0.110 \\
Solling & 0.008 & 0.007 & - & 0.003 & 0.129 \\
Reinhardswald & 0.007 & 0.007 & 0.008 & - & 0.129 \\
Wicklow & 0.059 & 0.074 & 0.094 & 0.094 & - \\
\hline
\end{tabular}

Table 6 Genetic differentiation for the $T f$ gene locus with respect to allelic structures (for details see text)

\begin{tabular}{llll}
\hline Origin & $\begin{array}{l}\text { Differentiation } D_{j} \\
\text { for all populations }\end{array}$ & $\begin{array}{l}\text { Continental } \\
\text { populations }\end{array}$ & $\begin{array}{l}\text { Natural } \\
\text { populations }\end{array}$ \\
\hline Lüneburger Heide & 0.197 & 0.248 & 0.278 \\
Harz & 0.197 & 0.248 & 0.278 \\
Solling & 0.180 & 0.133 & 0.105 \\
Nordhessen & 0.158 & 0.111 & 0.082 \\
Spessart & 0.200 & 0.153 & 0.127 \\
Soonwald & 0.206 & 0.160 & 0.133 \\
Achenkirch & 0.182 & 0.134 & 0.128 \\
Wicklow & 0.547 & excluded & excluded \\
Olderdissen & 0.091 & 0.044 & excluded \\
Reinhardswaldgatter & 0.219 & 0.219 & excluded \\
Opel & 0.174 & 0.128 & excluded \\
Lehmkaule & 0.212 & 0.264 & excluded \\
$\delta$ & 0.214 & 0.168 & 0.161 \\
$F_{\text {ST }}$ & 0.152 & & \\
\hline
\end{tabular}

Instead of such a clinal variation, the present study found a sharp boundary in allele frequencies between the Lüneburger Heide and the Harz population on the one hand and the remaining Continental populations on the other. However, the present study has also revealed similar allele frequencies for the Solling as well as the relatively low frequency of the rarer $T f$ allele in the Spessart population.

The present results show that there is no clear correlation of allele frequencies with geographic distance: in particular, the northernmost German populations Lüneburger Heide and Harz show allele frequencies similar to those that Bergmann (1976) found for the southernmost parts of Germany. Vice versa, the southernmost sampling site of the present study, the Austrian Achenkirch population, is more similar to the populations of the central part of Germany. These observations become more differentiated by calculating the genetic distances between the different sites.

\section{Heterozygosity}

In the context of maintenance of adaptability, multilocus heterozygosity, which requires data on genotypic in addition to allele frequencies, should also be considered. Estimates of the average degree of heterozygosity $\left(\bar{H}_{\mathrm{A}}\right)$ depend heavily on sample size and on the number of loci analysed (Nei, 1975; Nevo, 1978) and also on the protein loci examined. Moreover, a genetic analysis is lacking in most previous studies on natural deer populations. This means that different studies estimating heterozygosities for different sets of 'gene loci' are not a priori comparable. However, it has turned out that in the genus Cervus the differences between populations studied with the same set of protein loci are of the same magnitude and often greater than the differences between studies using different sets of proteins (see Baccus et al., 1983; Gyllensten et al., 1983; Hartle, 1986).

Average heterozygosities have been calculated for Lüneburger Heide, Harz, Solling, Reinhardswald and 
Wicklow using the data from the present study as well as from Herzog $(1988 \mathrm{a}, \mathrm{b})$. Table 3 gives the results for 12 monomorphic gene loci and the polymorphic 6$P G D, S O D$, as well as Tf. The heterozygosity of the Wicklow population represents the highest value found for the genus Cervus to date and is likely to be due to its hybrid origin. The heterozygosities of the four West German populations (see Table 3) fit into the framework given by the other European red deer populations. With the reservation of the above mentioned problems in comparing different studies on genetic variation in the genus Cervus, we found no indication for a reduced level of heterozygosity in the West German red deer populations.

\section{Genetic distances}

The differences in allele frequencies between the populations lead to striking differences in the genetic distances $d_{0}$ (Gregorius, 1974).

The data from Tables 4 and 5 show that $d_{0}$ and the commonly used $D$ (Nei, 1972) are only poorly correlated and not interchangeable. In particular, the two distances lead to different rankings of the populations. It is evident that $d_{0}$ allows a better discrimination between pairs of populations of low genetic distances.

Thus, the Tf locus enables consistent discrimination between red deer populations. The relatively large genetic distances between the Continental red deer populations and the Irish hybrid population are not unexpected. However, the genetic distances among the West German populations are also remarkable, and allow a clear discrimination, especially between Lüneburger Heide, Harz and the Lehmenkaule enclosure, and the other natural and enclosed populations (see Table 4).

The genetic distances between the natural West German populations are not just a function of geographical distances, but are also influenced by natural and artificial geographical barriers. In Central Europe, especially, this fragmentation is assumed to have an increasing influence on the populations of large wild animals and to promote their reproductive isolation into small subpopulations. Furthermore, the results provide evidence for genetic exchange between certain populations, e.g. between the Lüneburger Heide and the Harz populations. This is not surprising due to the well-known migrations of red deer, but it was surprising to find relatively large genetic distances between the Harz and the Solling population even though the geographical distances Lüneburger Heide-Harz and Solling-Harz (c. $50 \mathrm{~km}$ ) as well as potential obstacles (motorways, unwooded areas) are very similar. Migration between populations seems to depend heavily on the presence or absence of traditional haunts. Rivers seem to be a minor obstacle as, for example the similarities between Solling and Reinhardswald (divided by the Weser River) and even between Spessart and Soonwald (divided by the Rhein River) show.

\section{Differentiation}

Due to the sample size, gene frequencies instead of genotype frequencies were chosen for the measurement of differentiation ( $\delta_{\mathrm{ge}}$, Gregorius \& Roberds, 1986; Gregorius, 1988) in the present study. This, in addition, allows its direct comparison with the commonly used measure of 'variation between demes', $F_{\text {ST }}$ resp. $G_{\mathrm{ST}}$ (Wright, 1978 resp. Nei, 1973). The influence of the $T f$ gene locus on gene pool differentiation exceeds that of other previously studied polymorphic loci (Herzog, 1988a, b). Thus, Tf is the one relevant gene locus in our set of protein loci and therefore the $T f$ differentiation can be used instead of the gene pool differentiation.

Out of all populations covered by this study, the Irish hybrid population is the most differentiated. This result was not unexpected with respect to the allele frequencies. In this case, the $T f$ differentiation is one single measure that gives an evaluation of sika deer introgression into local Irish red deer populations.

Another question of practical interest is whether wild or enclosed populations originating from only a few animals can be representative of a number of wild populations or even a species. Thus, differentiation has been calculated for all Continental populations, i.e. all except the Wicklow population. The values $1-D_{j}$ (which can easily be calculated from Table 5) serve as representations of the total variation by the single populations. As the results show, Olderdissen $\left(1-D_{j}=\right.$ 0.956 ) is most representative, even more so than the natural populations $\left(1-D_{j}\right.$ ranging between 0.725 and 0.889 ). On the other hand, the Lehmankaule enclosure, which was founded in nearly the same way as Olderdissen, is the most differentiated $\left(1-D_{j}=0.736\right)$ and thus the least representative site.

The results provide evidence that even enclosures established with a very restricted number of individuals may be representative of a wide geographical range of natural populations. On the other hand, we know and it is also shown that mixing animals from different origins does not necessarily lead to a representation of some natural populations nor does it necessarily increase the genetic variability. This means that it is possible to maintain genetic variation even in populations originating from a very small number of animals, but it would require detailed knowledge of the genetic structures of a number of natural populations as well as of the 
sample used to found a new population.

Looking at only the natural populations (Table 6), it can be seen that the Lüneburger Heide and the Harz sites with $T f^{\mathrm{a}}$ and $T f^{\mathrm{b}}$ frequencies of nearly 50 per cent each are the most differentiated ones. Their relatively balanced allele frequencies make them less susceptible to accidental loss of genetic variation, i.e. in the present case fixation for one allele. On the other hand, a more asymmetric allele distribution would be representative of most of the Central European populations. Moreover, the rare $T f^{\mathrm{c}}$ is lacking from both the Lüneburger Heide and the Harz populations. The spatial differentiation being due to the spatial differences in allele frequencies has, regardless of its primary causes, an impact on wildlife management strategies. The importance of genetic conservation, and especially the maintenance of genetic variation, is becoming more commonly accepted. In this context, the results of the present study suggest two targets for future wildlife management efforts. One can be described as the preservation of adaptedness of local populations. Although we agree with Chesser et al. (1982) that the preservation of present electrophoretically detectable allele frequencies does not necessarily mean the preservation of unique and maybe locally adapted forms, we are of the opinion that we cannot neglect the risk of extinction of locally adapted populations $a$ priori. The second aim of wildlife management should be the maintenance of adaptability and thus of genetic variability per se. This would mean that we have to minimize the risk of any accidental loss of genetic variation. A first step in this direction should be the enlargement of the 'Rotwildgebiete' (hunt compartments) to units including a number of neighbouring populations. It would help to avoid the abovementioned risk of extinction of local adaptedness if only genetically similar populations (e.g. Lüneburger Heide and Harz or Solling and Reinhardswald) would be pooled. Another meaningful arrangement would be to allow and to support migration and therefore genetic exchange between neighbouring populations, but this is actually prohibited by the hunting legislation in some Central European countries.

\section{Acknowledgements}

The authors are most grateful to Dr Rory Harrington, Mammal Conservation Research Section, Wildlife Service, Republic of Ireland, for his good and helpful cooperation as well as, representative of many helpers, the Niedersächsische Landesforstverwaltung and the Hessische Landesforstverwaltung for providing additional blood samples. The excellent technical assistance of Christine Radler is gratefully acknow- ledged. The study was supported by the Deutsche Forschungsgemeinschaft.

\section{References}

BACCUS, R., RYMAN, N., SMITH, M. H., REUTERNALL, C. AND CAMERON, D. 1983. Genetic variability and differentiation of large grazing mammals. J. Mammalol., 64, 109-120.

BERGMANN, F. 1976. Beiträge zur Kenntnis der Infrastrukturen beim Rotwild. Teil II. Erste Versuche zur Klärung der genetischen Struktur von Rotwildpopulatonen an Hand von Serumprotein-Polymorphismen. Z. Jagdwissensch., 22, 28-35.

CAMERON, D. G. AND VYSE, E. R. 1978. Heterozygosity in Yellowstone Park elk, Cervus canadensis. Biochem. Genet., 16, 651-657.

CHESSER, R. K., REUTERWALl, C. AND RYMAN, N. 1982. Genetic differentiation of Scandinavian moose Alces alces populations over short geographical distances. OIKOS, 39, $125-130$.

GREGORIUS, H.-R. 1974. Genetischer Abstand zwischen Populationen. I. Zur Konzeption der Abstandsmessung. Silvae Genetica, 23, 22-27.

GREGORIUS, H.-R. 1987. The relationship between the concepts of genetic diversity and differentiation. Theor. Appl. Genet., 74, 397-401.

GREGORIUS, H.-R. 1988. The meaning of genetic variation within and between subpopulations. Theor. Appl. Genet., 76, 947-951.

GREGORIUS, H.R. AND ROBERDS, J. H. 1986. Measurement of genetical differentiation among subpopulations. Theor. Appl. Genet., 71, 826-834.

GYLLENSTEN, U., RYMAN, N., REUTERWALL, C. AND DRATCH, P. 1983. Genetic differentiation in four European subspecies of red deer (Cerbus elaphus L.). Heredity, 51, 561-580.

GYLLENSTEN, U., REUTERWALL, C., RYMAN, N. AND STÅHL, P. 1980. Geographical variation of transferrin allele frequencies in three deer species from Scandinavia. Hereditas, 92, 237-241.

HARTL, G. B. 1986. Genetische Variabilität beim Rotwild Auswirkungen anthropogener Einflüsse auf den Genpool von Wildtierpopulationen. C.I.C. Symposium Rotwild, Graz, 19.-22. Juni 1986, 423-431.

HARTL, G. B., SCHLEGER, A. AND SLOWAK, M. 1986. Genetic variability in fallow deer, Dama dama L. Anim. Genet., 17, 335-341.

HERZOG, S. 1988. Cytogenetische und biochemisch-genetische Untersuchungen an Hirschen der Gattung Cervus (Cervidae, Artiodactyla, Mammalia). Göttingen Res. Notes For. Genet., 10, 1-139.

HERZOG, S. 1988. Polymorphism and genetic control of erythrocyte 6-phosphogluconate dehydrogenase in the genus Cervus. Anim. Genet., 19, 291-294.

HERZOG, S. 1989. Genetic polymorphism of transferrin in fallow deer, Cervus dama L. Anim. Genet., 20, 421-426.

HERZOG, S. 1990. Genetic analysis of erythrocyte superoxide dismutase polymorphism in the genus Cervus. Anim. Genet., 21, 391-400. 
KRAVCHENKO, D. N. AND KRAVCHENKO, R. S. 1971. Polymorphous systems of blood serum proteins in Cervus elaphus L. Zitolog. Genet., 4, 311-315.

MCDOUGALL, E. I. AND LOWE, V. P. 1968. Transferrin polymorphism and serum proteins of some British deer. J. Zool., 155, 131-140.

MUSHÖVL, C. 1986. Serumtransferrine von Rotwild (Cervus elaphus $L$.) und Rehwild (Capreolus capreolus $L$.) Diss., Justus-Liebig-Universität Giessen.

NEI, M. 1972. Genetic distance between populations. Am. Nat., 106, 283-292.

NEI, M. 1973. Analysis of gene diversity in subdivided populations. Proc. Natl. Acad. Sci. USA, 70, 3321-3323.

NEI, M. 1975. Molecular Population Genetics and Evolution. North Holland Publishing Co., Amsterdam.

NEVO, E. 1978. Genetic variation in natural populations: patterns and theory. Theor. Pop. Biol., 13, 121-177.

PEMBERTON, J. M., ALBON, S. D., GUINNESS, F. E., CLUTTON-BROCK, T. H. AND BERRY, R. J. 1988. Genetic variation and juvenile survival in deer. Evolution, 43, 921-934.

PEMBERTON, J. M. AND SMITH, R. H. 1985. Lack of biochemical polymorphism in British fallow deer. Heredity, 55, 199-207.

TATE, M. W. AND ClellaNd, R. C. 1957. Nonparametric and Shortcut Statistics. Interstate Printers and Publishers, Danville.

WEBER, E. 1978. Mathematische Grundlagen der Genetik. VEB Gustav Fischer Verlag, Jena.

WrIGHT, s. 1978. Evolution and the Genetics of Populations, vol. 4: Variability Within and Among Natural Populations. The University of Chicago Press, Chicago. 